CLINICAL STUDY

\title{
Elevated serum levels of IGF-binding protein 2 in patients with non-seminomatous germ cell cancer: correlation with tumor markers $\alpha$-fetoprotein and human chorionic gonadotropin
}

\author{
Christian Fottner, Sabina Sattarova, Kerstin Hoffmann, Gerald Spöttl ${ }^{1}$ and Matthias M Weber \\ Schwerpunkt Endokrinologie und Stoffwechselerkrankungen, I. Medizinische Klinik und Poliklinik der Johannes Gutenberg Universität Mainz, \\ Langenbeckstrasse 1, 55131 Mainz, Germany and ${ }^{1}$ Medizinische Klinik II, Klinikum Grosshadern, Ludwig-Maximilians-Universität München, München, \\ Germany \\ (Correspondence should be addressed to C Fottner; Email: fottner@endokrinologie.klinik.uni-mainz.de)
}

\begin{abstract}
Background/aims: Alterations of the IGF system have been described in several different types of cancer. However, no information is available about the role of the IGF system in patients with nonseminomatous germ cell cancer.

Methods: Free IGF-I, IGF-II, acid-labile subunit, and IGF-binding proteins (IGFBPs) 1-4 were analyzed by specific RIAs in 32 patients with untreated non-seminomas and compared with IGFBP levels of 38 healthy controls. Serum IGFBPs were analyzed by western ligand blotting (WLB) and immunoblotting. In 16 patients, IGFBP profiles were measured before, during, and after treatment.

Results: In patients with testicular cancer, IGF-II levels were on average 1.44-fold higher than in the healthy control group $(1027 \pm 48 \mathrm{ng} / \mathrm{ml}$ versus $711 \pm 30 \mathrm{ng} / \mathrm{ml}, P<0.0001)$. IGFBP-2 levels were on average 2.6-fold higher $(586 \pm 58 \mathrm{ng} / \mathrm{ml}$ versus $226 \pm 17 \mathrm{ng} / \mathrm{ml}, P<0.001)$. During follow-up, a decrease in IGFBP-2 levels was observed in all successfully treated patients, which correlated closely with a decrease in the tumor markers $\alpha$-fetoprotein and human chorionic gonadotropin. Additionally, in all patients with recurrent disease, a significant further increase in IGFBP-2 levels (from $358 \pm 97$ to $976 \pm$ $260 \mathrm{ng} / \mathrm{ml}$ ) was detected. IGFBP-3 levels, as measured by RIA, were not different in patients with testicular cancer compared with controls. However, WLB analysis demonstrated markedly decreased intact IGFBP-3 bands in untreated patients and a significant increase after successful therapy.

Conclusion: Our results demonstrate that markedly elevated IGF-II and IGFBP-2 serum levels in patients with non-seminomatous germ cell cancer, showing a significant decrease after successful therapy and an increase in recurrent disease. Additionally, indirect evidence points to an increased proteolytic activity for IGFBP-3 in untreated testicular cancer patients.
\end{abstract}

European Journal of Endocrinology 159 317-327

\section{Introduction}

Testicular germ cell tumors are the most common malignancies in young men, and the incidence is increasing worldwide (1). Testicular tumors can broadly be divided into germ cell and non-germ cell tumors. The vast majority (90-95\%) of tumors are germ cell tumors, while the remainder are sex cord-stromal tumors, mixtures, and tumors arising in paratesticular tissues. Germ cell tumors are further divided into seminomatous and non-seminomatous germ cell tumors (seminomas and non-seminomas). Non-seminomas can be further classified histologically into embryonal carcinomas, teratomas (mature and immature), choriocarcinomas, yolk sac tumors, and tumors with mixed histological features (2). Prognosis and choice of the adequate therapeutic regimen are dependant on tumor stage and additional clinical criteria, in particular with regard to the extent of tumor marker elevation (3-6). Testicular germ cell tumors are thought to be derived from cells in the germ cell lineage at different stages of development, which are blocked in maturation (2). All testicular germ cell tumors progress through a non-invasive stage termed intratubular germ cell neoplasia unclassified or carcinoma in situ. Several factors have been associated with their pathogenesis, including cryptorchidism, elevated estrogens in utero, gonadal dysgenesis, and androgen insensitivity syndromes $(7,8)$.

The insulin-like growth factors I and II (IGF-I and -II) are polypeptides, playing a key role in cellular metabolism, differentiation, proliferation, transformation, and apoptosis during normal development and malignant growth. Both, IGF-I and -II, are structurally related to proinsulin and secreted in an endocrine and paracrine/autocrine manner respectively. Both proteins mainly mediate their mitogenic effects by binding to the IGF-receptor type I $(9,10)$, which exhibits a high affinity for both IGFs. The IGFs also exhibit a high binding affinity to at least six 
specific IGF-binding proteins (IGFBPs 1-6), a family of structurally related peptides that are locally synthesized by most tissues and secreted in tissue-specific patterns. These peptides are capable of both inhibiting and enhancing IGF action and even have ligand-independent effects $(10,11)$. There is a growing body of evidence showing that the IGF system controls growth and proliferation of several types of cancer. Epidemiological observations indicate that circulating IGF-I levels are positively associated with an increased risk for the development of several common tumors such as breast, colorectal, lung, prostate, and ovarian cancers. Additionally, overexpression of IGF-II and different IGFBPs are found in these types of cancer $(8,12)$. IGF-I signaling has been shown to contribute to each stage of tumorigenesis: malignant transformation, tumor growth, local invasion, distant metastases, and resistance to treatment.

Although all components of the IGF system have been characterized in normal human testicular cells (13-15), in contrast to the above-mentioned malignant tumors, no information is available on the role of the IGF system in testicular cancer. The few previously reported studies, using either immunohistochemical investigation of the IGF system in testicular intratubular germ cell neoplasias or RT-PCR analysis in a small number of germ cell tumors $(14,16)$, show contradictory results, reporting upregulation of some components of the IGF system in early tumor stages (pT1), whereas downregulation of the same IGFBPs is reported for advanced tumor stages. Furthermore, in contrast to almost all other previously published data, a downregulation of the IGF-II mRNA has been reported in this study for seminomas, whereas other published data show a strong IGF-II mRNA expression in two of three germ cell cancers, with the strongest IGF-II expression seen in one embryonal carcinoma (17). Therefore, the aim of the study was to assess possible changes in circulating serum IGF and IGFBP profiles in patients with nonseminomatous testicular cancer during and after treatment and to correlate these findings with tumor markers, tumor stage, and other clinical criteria such as the response to treatment and the risk of recurrence.

\section{Materials and methods}

In this study, free IGF-I and -II, acid-labile subunit (ALS), and IGFBPs 1-4 were analyzed by specific RIA/IRMA in 32 patients with untreated non-seminomatous germ cell cancer (mean age $30.6 \pm 1.7$ years) and, as IGF ligands and binding proteins are age and sex dependent compared with IGF and IGFBP levels of 38 healthy age- and sexmatched controls (mean age $31.3 \pm 1.3$ years). IGF and IGFBP levels in healthy controls were found to be within the normal range reported for this age group (18). Additionally, serum IGFBPs were analyzed by western ligand blotting (WLB). Pooled serum of the 38 healthy control patients has been used as an internal control for the IGFBP analysis of the patient's serum samples by WLB.
For quantitative measurement of IGFs, IGFBPs, and tumor markers, serum samples of the patients were collected the day before starting chemotherapy and/or the surgical procedure to remove the testicular primary tumor in the few patients requiring no chemotherapy. Serum samples were stored immediately at $-20{ }^{\circ} \mathrm{C}$ until further analysis. The study was performed according to the guidelines of the local ethical committee and all patients gave written informed consent. In 16 non-seminoma patients, IGFBP profiles were measured before, during, and after treatment for a mean follow-up period of $9.8 \pm 2.1$ months and correlated with the tumor markers $\alpha$-fetoprotein (AFP) and human chorionic gonadotropin (HCG) (as measured by specific RIA). In 6 of these 16 patients, recurrent disease was observed as verified by an increase in tumor markers and by morphological imaging procedures (computed tomography/magnetic resonance imaging scan). In these patients, serum samples have been collected for evaluation of IGFs, IGFBPs, and tumor marker serum levels before starting second or third line chemotherapy. The blood sampling for both the tumor markers and the samples for IGFBP and IGF analyses were performed at day 0 , directly before starting chemotherapy, except for patients 3 and 8 (Table 1), where the blood sampling was performed at days 3 and 7 after initiation of therapy. To better correlate IGF and IGFBP with the highly specific and sensitive tumor markers AFP and HCG, the study was confined to non-seminomatous germ cell tumors, showing a significant tumor marker elevation. For a detailed overview of the histological characteristics, tumor stage and specific treatment of the patients (see Table 1).

(3- ${ }^{125}$ I-iodotyrosyl) IGF-I (human recombinant, specific activity $2000 \mathrm{Ci} / \mathrm{mmol}$ ) for WLB was purchased from Amersham Buchler $\mathrm{GmbH} \&$ Co KG. IGFBP-3 antiserum for western immunoblotting (IGFBP-3 antibody specific to the $\mathrm{COOH}$-terminal domain of IGFBP-3, $0.2 \mu \mathrm{g} / \mathrm{ml}$ ) was purchased from Santa Cruz Biotechnology, Inc. (Santa Cruz, CA, USA).

\section{RIAs}

Free IGF-I and -II, ALS, and IGFBPs 1-4 were measured by highly sensitive and specific IRMA/RIA kits or ELISA from Diagnostic Systems Laboratories DSL, Webster, TX, USA (free IGF-I IRMA \#9400, IGF-II IRMA w/Extraction \# 9100, ALS ELISA \# 10-820, total IGFBP-1 IRMA \# 7800, IGFBP-2 double Antibody RIA \# 7100, total IGFBP-3 IRMA \# 6600, IGFBP-4 ELISA \# 10-7300), as described previously (19). All assays have been validated for the use in human serum or plasma and their intra- and interassay coefficients of variation were less than 8 and 10\% respectively. HCG and AFP determinations were performed using a double monoclonal IRMA (HCG) and a conventional RIA (AFP) as described previously (20). 
Table 1 Characteristics, therapy, and outcome of 32 patients with testicular germ cell cancer.

\begin{tabular}{|c|c|c|c|c|c|c|c|c|c|c|c|c|c|c|c|}
\hline Patients & Age & Histology & $\begin{array}{l}\text { TNM } \\
\text { stage }\end{array}$ & $\begin{array}{l}\text { Initial } \\
\text { treatment }\end{array}$ & $\begin{array}{l}\text { AFP } \\
\text { before } \\
\text { treatment }\end{array}$ & $\begin{array}{l}3 \\
\text { months }\end{array}$ & $\begin{array}{l}\text { Relapse } \\
\text { (day) }\end{array}$ & $\begin{array}{l}\text { HCG } \\
\text { before } \\
\text { treatment }\end{array}$ & $\begin{array}{l}3 \\
\text { months }\end{array}$ & Relapse & $\begin{array}{c}\text { IGFBP-2 } \\
\text { before } \\
\text { treatment }\end{array}$ & $\begin{array}{l}3 \\
\text { months }\end{array}$ & Relapse & $\begin{array}{l}\text { IGF-II } \\
\text { before } \\
\text { Tx }\end{array}$ & $\begin{array}{l}\text { Further } \\
\text { treatment }\end{array}$ \\
\hline 1 & 23 & $\mathrm{TC}$ & II & $\begin{array}{l}\text { Prim. } \\
\text { RPLND } \\
\text { ECBC } \times 4\end{array}$ & 1650 & & & 2 & & & 413 & & & 1087 & \\
\hline 2 & 30 & $\mathrm{~T}(\mathrm{~m})$ & II & $\begin{array}{l}\text { PEB } \times 4 \\
\text { Sek. } \\
\text { RPLND }\end{array}$ & 630 & & & 1309 & & & 358 & & & 1688 & \\
\hline 3 & 34 & $\mathrm{CC}$ & III & $\begin{array}{l}\text { PEB } \times 4 \\
\text { Sek. } \\
\text { RPLND }\end{array}$ & 21 & & & 694411 & & & 641 & & & 958 & \\
\hline 4 & 29 & EC & II & $\begin{array}{l}\text { PEB } \times 4 \\
\text { Sek. } \\
\text { RPLND }\end{array}$ & 109 & & & 3393 & & & 497 & & & 988 & \\
\hline 5 & 24 & EC & III & $\begin{array}{c}\text { PEB } \times 4 \\
\text { Sek. } \\
\text { RPLND }\end{array}$ & 92 & & & 455 & & & 453 & & & 966 & \\
\hline 6 & 25 & EC & II & $\mathrm{PEB} \times 3$ & 107 & & & 3674 & & & 843 & & & 910 & \\
\hline 7 & 43 & $\mathrm{CC}$ & II & $\begin{array}{r}\mathrm{ECBC} \times 3 \\
\mathrm{CEB} \times 1\end{array}$ & 4 & & & 34290 & & & 324 & & & 1165 & \\
\hline 8 & 35 & EC & III & $\begin{array}{l}\text { Prim. } \\
\text { RPLND } \\
\text { ECBC } \times 4\end{array}$ & 3 & & & 1139 & & & 226 & & & 899 & \\
\hline 9 & 24 & $\mathrm{~T}(\mathrm{~m})$ & I & $\begin{array}{l}\text { Prim. } \\
\text { RPLND } \\
\text { PEB } \times 3\end{array}$ & 4187 & & & 2790 & & & 89 & & & 688 & \\
\hline 10 & 24 & EC & II & $\begin{array}{l}\text { Prim. } \\
\text { RPLND } \\
\text { PEB } \times 4\end{array}$ & 358 & & & 77 & & & 644 & & & 1120 & \\
\hline 11 & 26 & $T(m)$ & II & $\mathrm{PEB} \times 3$ & 855 & & & 379 & & & 645 & & & 1201 & \\
\hline 12 & 24 & $\mathrm{EC}$ & II & $\mathrm{PEB} \times 3$ & 276 & & & 2856 & & & 230 & & & 1254 & \\
\hline 13 & 31 & $\mathrm{~T}(\mathrm{im}) / \mathrm{S}$ & II & $\begin{array}{l}\text { ECBC } \times 4 \\
\text { Sek. } \\
\text { RPLND }\end{array}$ & 19500 & & & 213 & & & 467 & & & 944 & \\
\hline 14 & 26 & EC & II & PEB $\times 3$ & 3 & & & 2257 & & & 421 & & & 498 & \\
\hline 15 & 24 & $\mathrm{~T}(\mathrm{~m})$ & II & $\begin{array}{l}\text { PEB } \times 3 \\
\text { Sek. } \\
\text { RPLND }\end{array}$ & 243 & & & 149 & & & 343 & & & 1165 & \\
\hline 16 & 27 & $\mathrm{~T}(\mathrm{im})$ & ॥ & $\begin{array}{l}\text { Prim. } \\
\text { RPLND } \\
\text { PEB } \times 4\end{array}$ & 269 & & & 499 & & & 282 & & & 699 & \\
\hline 17 & 35 & $T(m)$ & III & $E C B C \times 4$ & 12838 & 35 & & 127726 & 31 & & 1028 & 861 & & 899 & \\
\hline 18 & 31 & $\mathrm{EC}$ & III & $\begin{array}{l}\text { PEB } \times 2 \\
\text { Sek. } \\
\text { RPLND } \\
\text { PEB } \times 3\end{array}$ & 436 & 6 & & 180 & 2 & & 1469 & 319 & & 798 & \\
\hline 19 & 33 & $\mathrm{EC}$ & III & $E C B C \times 4$ & 2700 & 7 & & 69 & 2 & & 837 & 415 & & 899 & \\
\hline 20 & 35 & EC & II & $\mathrm{CEB} \times 4$ & 53 & 4 & & 123 & 2 & & 1222 & 910 & & 1032 & \\
\hline 21 & 22 & TC & III & $\begin{array}{l}\text { PEI } \times 4 \text { Sek. } \\
\text { RPLND }\end{array}$ & 51000 & 35 & & 19 & 2 & & 585 & 459 & & 1114 & \\
\hline 22 & 51 & EC & III & $\mathrm{PEB} \times 4$ & 3 & 3 & & 4659 & 248 & & 1067 & 1271 & & 1655 & \\
\hline
\end{tabular}


Table 1 Continued

\begin{tabular}{|c|c|c|c|c|c|c|c|c|c|c|c|c|c|c|c|}
\hline Patients & Age & Histology & $\begin{array}{l}\text { TNM } \\
\text { stage }\end{array}$ & $\begin{array}{l}\text { Initial } \\
\text { treatment }\end{array}$ & $\begin{array}{l}\text { AFP } \\
\text { before } \\
\text { treatment }\end{array}$ & $\begin{array}{l}3 \\
\text { months }\end{array}$ & $\begin{array}{l}\text { Relapse } \\
\text { (day) }\end{array}$ & $\begin{array}{l}\text { HCG } \\
\text { before } \\
\text { treatment }\end{array}$ & $\begin{array}{l}3 \\
\text { months }\end{array}$ & Relapse & $\begin{array}{l}\text { IGFBP-2 } \\
\text { before } \\
\text { treatment }\end{array}$ & $\begin{array}{l}3 \\
\text { months }\end{array}$ & Relapse & $\begin{array}{l}\text { IGF-II } \\
\text { before } \\
\text { Tx }\end{array}$ & $\begin{array}{l}\text { Further } \\
\text { treatment }\end{array}$ \\
\hline 23 & 59 & EC & ॥ & $\begin{array}{r}\mathrm{ECBC} \times 1 \\
\mathrm{PEI} \times 3\end{array}$ & 3 & 3 & & 2 & 2 & & 397 & 801 & & 765 & \\
\hline 24 & 29 & $\mathrm{EC}$ & III & $\begin{array}{l}\text { ECBC } \times 4 \\
\text { Sek. } \\
\text { RPLND }\end{array}$ & 4736 & 5 & & 2 & 2 & & 599 & 383 & & 678 & \\
\hline 25 & 42 & $T(m) / S$ & ॥ & $\mathrm{PEB} \times 3$ & 3 & 3 & & 2 & 2 & & 857 & 380 & & 794 & \\
\hline 26 & 30 & $\mathrm{CC}$ & III & $\mathrm{ECBC} \times 4$ & 65 & 3 & & 705130 & 31 & & 1028 & 711 & & 856 & TIP-CET $\times 3$ psc-Tx \\
\hline 27 & 26 & $\mathrm{CC}$ & III & $\mathrm{PEB} \times 4$ & 3 & 4 & $3(231)$ & 567 & 2 & 786600 & 662 & 811 & 1166 & 1206 & $\operatorname{TIP} \times 3$ \\
\hline 28 & 29 & $\mathrm{~T}(\mathrm{~m})$ & III & $\mathrm{ECBC} \times 4$ & 13 & 6 & $4(280)$ & 9798 & 2 & 382 & 388 & 124 & 450 & 1165 & TIP-CET $\times 3$ psc-Tx \\
\hline 29 & 19 & CC/YS/EC & III & $\mathrm{ECBC} \times 4$ & 1735 & 3 & $\begin{array}{l}1193 \\
(309)\end{array}$ & 880000 & 2 & 170532 & 167 & 523 & 976 & 1001 & $\mathrm{PEI} \times 4$ \\
\hline 30 & 20 & $\mathrm{EC} / \mathrm{S}$ & III & $\mathrm{PEB} \times 4$ & 6621 & 10 & $\begin{array}{l}5950 \\
(484)\end{array}$ & 2 & 2 & 2 & 766 & 716 & 1377 & 1355 & PEI $\times 4$ TIP-CET $\times 3$ psc-TX \\
\hline 31 & 42 & $\mathrm{~T}(\mathrm{im})$ & III & $\mathrm{ECBC} \times 4$ & 85 & 3 & $3(531)$ & 8939 & 2 & 65298 & 533 & 336 & 1498 & 1000 & TIP-CET $\times 3$ psc-Tx \\
\hline 32 & 26 & $\mathrm{EC} / \mathrm{S}$ & III & $\begin{array}{l}\text { Prim. } \\
\text { RPLND } \\
\text { PEB } \times 4 \\
\text { PEI } \times 2\end{array}$ & 754 & 4 & $4(2034)$ & 129 & 2 & 380 & 724 & 627 & 390 & 1231 & PEI $\times 4$ TIP-CET $\times 3$ psc-Tx \\
\hline
\end{tabular}

AFP, $\alpha$-fetoprotein; HCG, human chorionic gonadotropin; IGF-II, insulin-like growth factor-II; Tx, transplantation; IGFBP-2, insulin-like growth factor binding protein-2; RPLND, retroperitoneal lymph node dissection; PEB, cisplatin, etoposide, bleomycin: CEB, carboplatin, etoposide, bleomycin; PEI, cisplatin, etoposide, ifosfamide; TIP-CET, paclitaxel/ifosfamide/cisplatin-high-dose carboplatin/etoposide/thiotepa; Tax-IfoC, taxol/ifosfamide/cisplatin; ECBC, cisplatin, etoposide, bleomycin, cyclophosphamide; psc-Tx, peripheral stem cell transplantation; EC, embryonal carcinoma; CC, choriocarcinoma; YS, yolk sac tumor; $\mathrm{S}$, seminoma; T, teratoma; $(\mathrm{m})$, mature; (im), immature; TC, teratocarcinoma (embryonal carcinoma with teratoma). 


\section{WLB}

The IGFBPs were characterized in the serum samples as described previously (21). In brief, $10 \mu \mathrm{l}$ of the serum samples were separated by $12 \%$ SDS-PAGE under nonreducing conditions in a Laemmli buffer system. Proteins were electrotransblotted onto PVDF membranes (Imobilon, Millipore, Munich, Germany). The IGFBPs were identified by autoradiography following overnight incubation of the filters with ${ }^{125}$ I-labeled IGF-I at $4^{\circ} \mathrm{C}$.

\section{Western immunoblotting}

Samples were subjected to non-reducing gel electrophoresis and electrotransfered to PVDF-membrane as described previously. The membrane was blocked with $5 \%$ BSA and $0.1 \%$ Tween-20 in PBS for $12 \mathrm{~h}$ prior to incubation with the IGFBP-3 antiserum in PBS containing $1 \%$ BSA and $0.1 \%$ Tween-20 for $3 \mathrm{~h}$. The PVDF membranes were washed twice with PBS containing $0.1 \%$ Tween-20 and incubated with a peroxidase-labeled second antibody for another $2 \mathrm{~h}$. The membranes were then washed extensively for $1 \mathrm{~h}$ with PBS containing $0.1 \%$ Tween-20, and the immune complexes were stained using a horseradish peroxidase technique as described previously (22). Quantitative evaluation of the binding proteins visualized by ligand blotting and IGFBP-3 degradation was carried out by densitometric scanning of the bands with the ImageScanner III System (GE-Healthcare Bio-Sciences AB, Uppsala, Sweden) and using NIH Image 1.63 software (23).

\section{Statistical analysis}

All data are expressed as mean \pm s.E.M. Comparative data were analyzed by multivariate analysis and paired $t$-test with significance defined as $P<0.05$, unless otherwise mentioned.

\section{Results}

\section{IGF-II and IGFBP-2 serum levels are elevated in patients with testicular cancer}

In our study, serum levels for IGF-I and -II were analyzed in 32 patients with untreated testicular cancer (for detailed information of patient characteristics, see Table 1) and compared with healthy age- and sexmatched controls. For plasma-free IGF-I serum levels, no difference could be observed $(222 \pm 8 \mathrm{ng} / \mathrm{ml}$ versus $209 \pm 16 \mathrm{ng} / \mathrm{ml})$. By contrast, IGF-II levels were on average 1.44-fold higher in patients with untreated testicular cancer than in the healthy control group $(1027 \pm 48 \mathrm{ng} / \mathrm{ml}$ versus $711 \pm 30 \mathrm{ng} / \mathrm{ml}, P<0.0001$; Fig. 1). ALS levels (data not shown) tended to be higher in the tumor group but did not reach statistical significance $(34.7 \pm 1.8$ vs $30.7 \pm 1.1)$.

In addition to the analysis of IGF serum levels, quantitative determination of the IGFBPs 1-4 was performed. Western ligand blot analysis of the serum samples showed IGFBPs 1-4 being the predominant IGFBPs in the serum samples of the tumor patients and the healthy controls, similar to the data reported in the literature for normal human serum. Due to the large sample size required for both the ligand blot and the different RIA/IRMA analyses, quantitative determination of IGFBP- 5 and -6 had to be spared. When IGFBP-1, -3 , and -4 serum levels were measured by RIA/IRMA no statistically significant differences were found in both groups (Fig. 2). Even though the IGFBP-4 serum levels tended to be higher in patients with testicular cancer, binding protein levels did not reach statistical significance. By contrast, IGFBP-2 serum levels were found to be significantly higher in patients with testicular cancer. In patients with untreated non-seminomatous germ cell cancer, the IGFBP-2 serum levels were on an average 2.6fold higher than in the healthy control group (Fig. 2). The normal serum IGFBP-2 levels in the healthy control group were within the normal range of serum IGFBP-2 levels

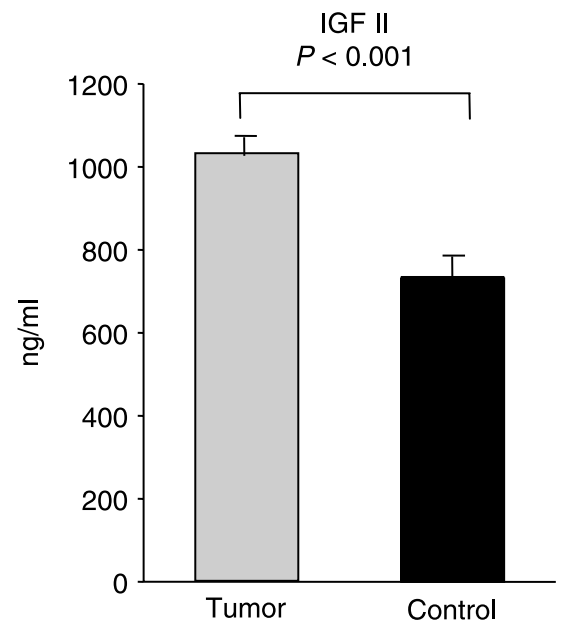

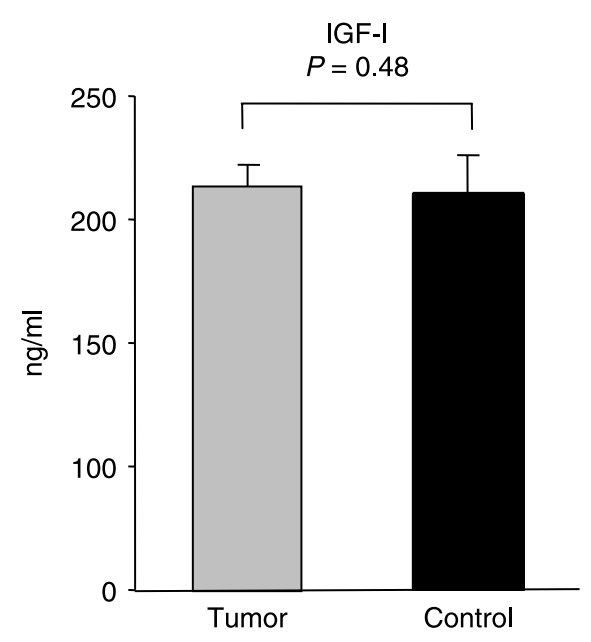

Figure 1 Free IGF-I and -II serum levels in 32 patients with untreated testicular cancer compared with sex- and agematched healthy control patients. 

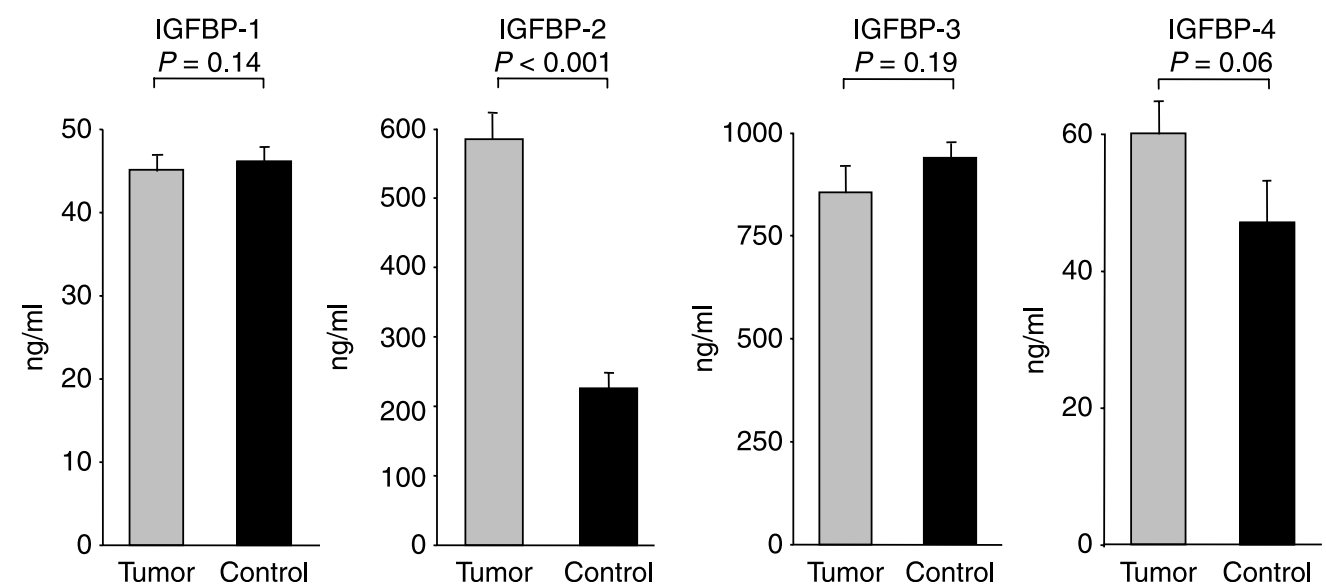

Figure 2 IGFBPs 1-4 serum levels in 32 patients with untreated testicular cancer compared with sex- and age-matched healthy control patients.

reported for this age group in the literature (10). When IGFBP-2 levels were graded according to the tumor stage, a correlation between tumor stage and IGFBP-2 serum levels was found (IGFBP-2 $89.00 \mathrm{ng} / \mathrm{ml}$ for stage I $(n=1)$, $528.93 \mathrm{ng} / \mathrm{ml}$ for stage II $(n=15)$, and $698.31 \mathrm{ng} / \mathrm{ml}$ for stage III $(n=16))$. However, due to the small sample number of stage I patients, the differences in IGFBP-2 levels did not reach statistical significance.

\section{IGFBP-2 serum levels show a significant decrease after successful therapy}

In 16 patients with testicular cancer, IGFBP levels were analyzed before, during, and after therapy. All investigated patients received chemotherapy due to an advanced tumor stage and IGFBP serum levels were investigated for a mean follow-up period of $9.8 \pm 2.1$ months. IGFBP-1, -3, and -4 serum levels did not show any significant changes after primary successful therapy as verified by normalization of tumor markers and a tumor regression on imaging procedures (Fig. 3).
Serum levels remained constant during the whole period of investigation.

However, a significant decrease in IGFBP-2 levels after successful therapy was noted as early as 3 months after the start of therapy (Fig. 3). In all 16 investigated patients, a continuing decrease in IGFBP-2 levels during the first 6 months after initiation of therapy could be observed in both the western ligand blot analysis and the IGFBP-2 RIA (Fig. 4). Overall IGFBP-2 serum levels decreased on an average $60 \%$. After 3 months, significantly lower IGFBP-2 levels were found in $90 \%$ of all investigated patients (Fig. 5). After 6 months of therapy a significant decrease of IGFBP-2 levels was observed in all patients. In all patients with a complete remission of tumor disease, IGFBP-2 remained at constant levels not different from those measured in the healthy control group and did not further change (Fig. 5A). In parallel to the decrease in IGFBP-2 serum concentration, a constant but less pronounced decrease in IGF-II serum levels was observed (Fig. 5B). However, significantly lower serum concentrations were found only 12 months after initiation of therapy.
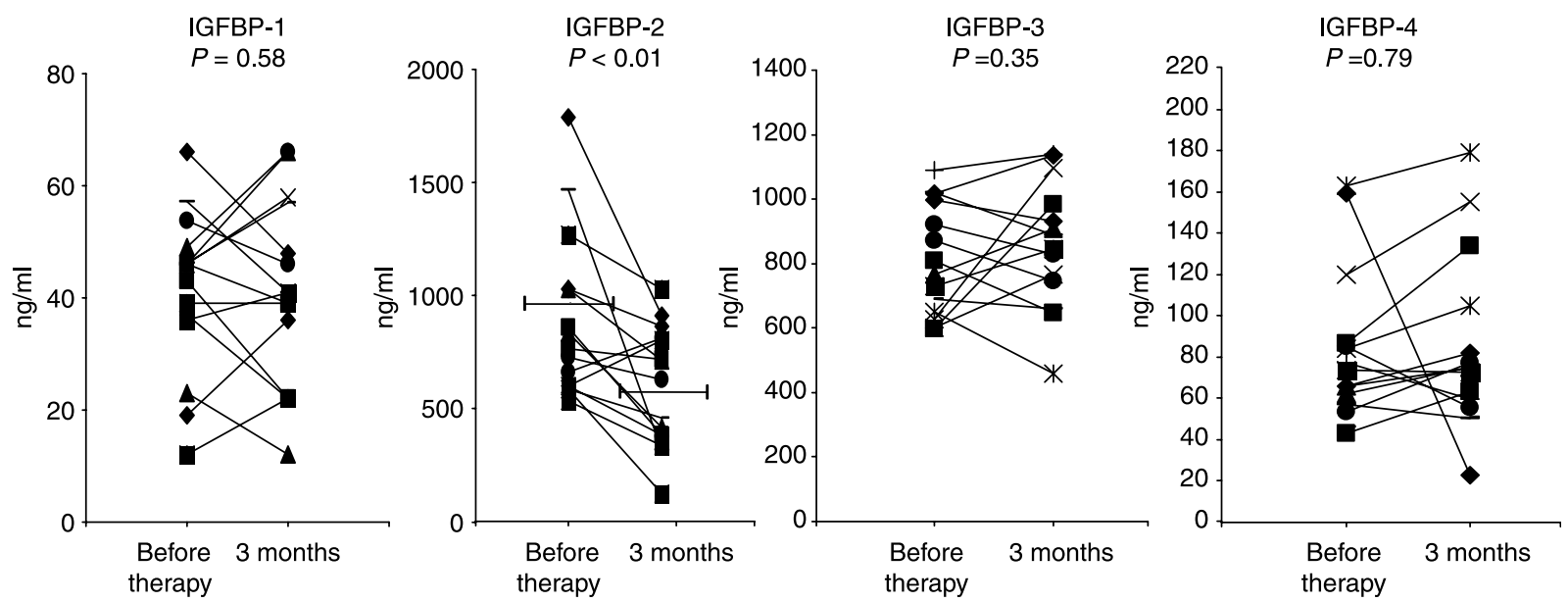

Figure 3 IGFBPs 1-4 serum levels in 16 patients with testicular cancer, before and 3 months after initiation of therapy. 

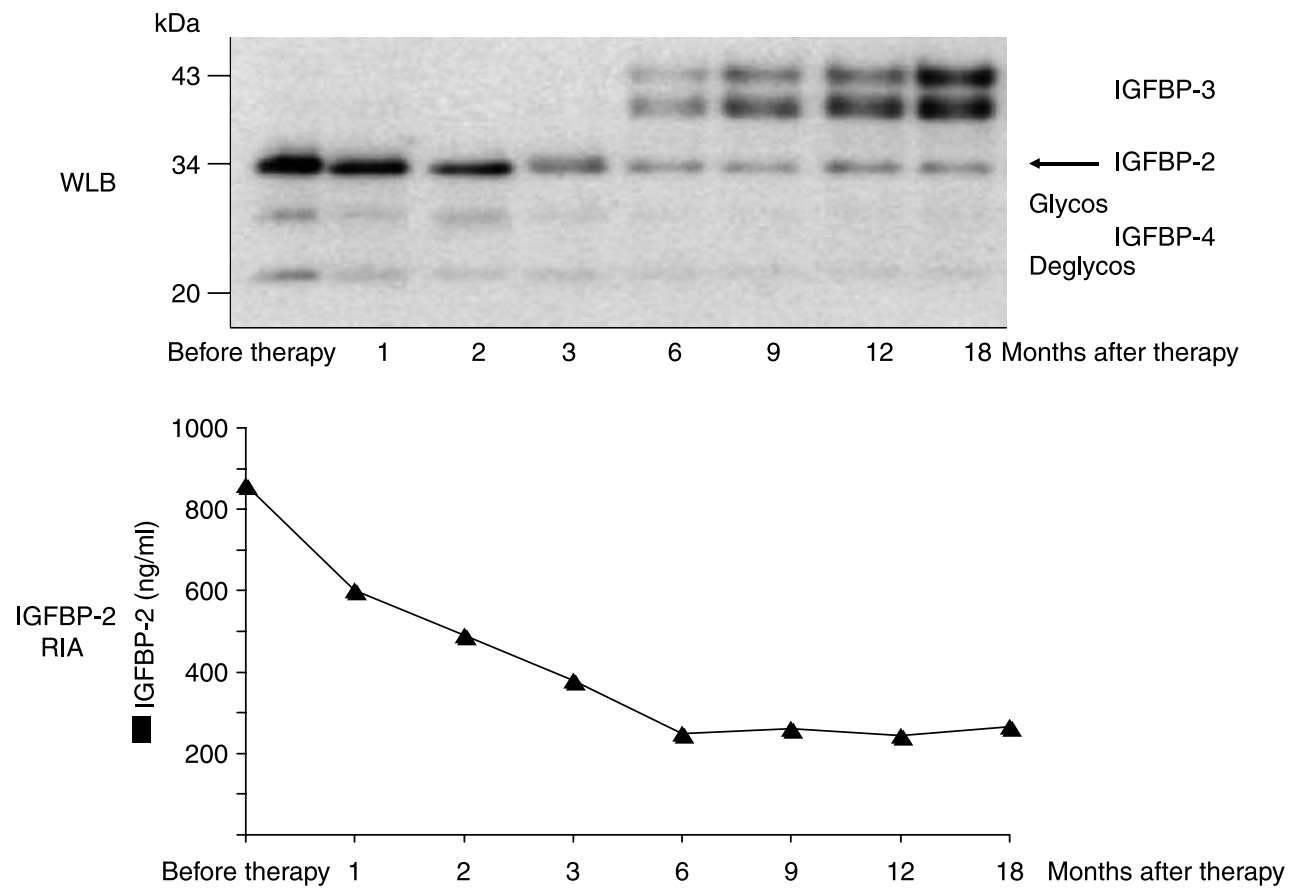

Figure 4 Western ligand blot analysis (WLB) of serum IGF-binding proteins and quantitative determination of IGFBP-2 serum concentrations (IGFBP-2 RIA) in one representative patient with non-seminomatous germ cell cancer before, during, and after therapy.

\section{Increase in IGFBP-2 serum levels correlate with tumor markers AFP and HCG}

The decline in IGFBP-2 serum levels after successful therapy was in good correlation with the clinical history of the patients and the monitored tumor markers AFP and HCG, highly sensitive and specific tumor markers used for the diagnosis and monitoring of therapy in patients with testicular cancer. In parallel to the fall in IGFBP-2 levels, the tumor markers AFP and HCG did show a rapid decrease during therapy showing a significant correlation with the IGFBP-2 levels ( $r=0.62$ and 0.69 respectively; $P<0.01)$. Three months after successful therapy, tumor markers returned to high normal levels and then remained constant in the low normal range during further follow-up.

\section{IGFBP-2 serum levels show a significant increase in recurrent disease}

When IGFBP-2 serum levels were investigated in patients with recurrent disease, initially a similar decrease in IGFBP-2 serum levels after chemotherapy could be observed (from 614.6 \pm 77.3 to $358.1 \pm$ $97.5 \mathrm{ng} / \mathrm{ml} ; P<0.01$ ), with a significant decrease in IGFBP-2, 6 months after primarily successful therapy in parallel to the normalized tumor markers. However, at the time of relapse (median 397 days), a significant on average 2.7-fold further increase in IGFBP-2 levels could be detected with an increase in IGFBP-2 from initially $358.1 \pm 97.5$ to $976.1 \pm 260.3 \mathrm{ng} / \mathrm{ml}$, which
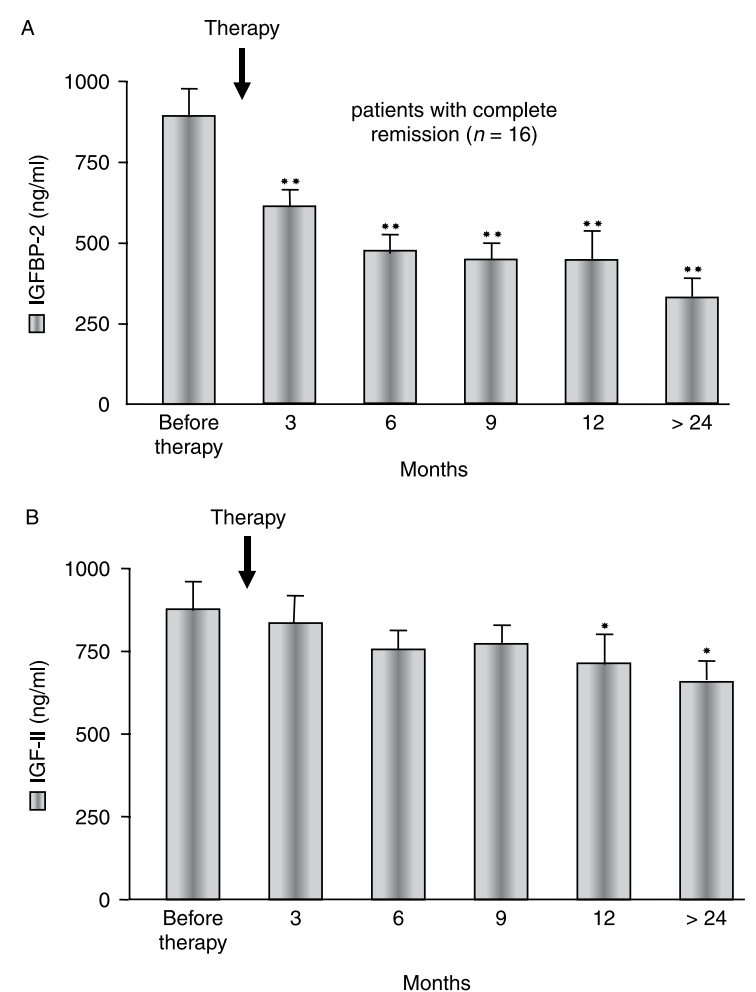

Figure 5 (A) IGFBP-2 and (B) IGF-II serum levels before, during, and after therapy in 16 patients with testicular cancer, showing a complete remission of the tumor disease after primary successful chemotherapy $\left({ }^{\star} P<0.05\right.$; $\left.{ }^{\star \star} P<0.01\right)$. 
paralleled the clinical history of recurrent disease and the rise in tumor marker levels.

\section{Increased proteolytic activity for IGFBP-3 in untreated testicular cancer patients}

As shown previously, in contrast to IGFBP-2, IGFBP-3 serum levels as measured by RIA were not different in patients with testicular cancer compared with the healthy control group and did not change during follow-up (Figs 2 and 3). However, western ligand blot analysis using radioactive IGF-I as specific tracer and therefore detecting only intact forms of IGFBP-3, demonstrated markedly decreased IGFBP-3 bands in untreated patients with testicular cancer with a significant increase in intact IGFBP-3 bands after successful therapy (Figs 4 and 6A). To detect fragments of IGFBP-3, we additionally performed western immunoblots with specific anti-IGFBP-3 antibodies to further evaluate possible proteolytic degradation of IGFBP-3 as a potential explanation of decreased total IGFBP-3 as demonstrated by western ligand blot analysis (Fig. 6B). Western immunoblot analysis revealed large amounts of the major $30 \mathrm{kDa}$ fragment of IGFBP-3 in untreated patients with testicular cancer and smaller amounts of IGFBP-3 fragments with 16 and $22 \mathrm{kDa}$. In parallel to the increase in intact IGFBP-3 as measured by densitometric quantification (Fig. 6C), a decrease in the IGFBP-3 fragments seemed to occur, giving indirect evidence of an enhanced proteolysis of IGFBP-3 in untreated testicular cancer patients.

\section{Discussion}

The overexpression of IGF-II and IGFBP-2 mRNA has already been reported in different types of testicular tumors $(14,16,17)$. However, published data show contradictory results and to date, nothing was known on possible alterations of the IGF system in patients with testicular cancer on the protein-level in vivo. The present study is the first to demonstrate markedly elevated IGFII and IGFBP-2 serum levels in patients with nonseminomatous germ cell cancer, showing a significant decrease after successful therapy and an increase in recurrent disease with good correlation with the tumor markers AFP and HCG.

Increased serum IGF-II and IGFBP-2 levels are found in patients suffering from various different kinds of malignancies such as lung, colorectal, adrenocortical, ovarian, prostate, and CNS cancers as well as in patients with lymphoid tumors and in children suffering from Wilms' tumor (24-28). In several of these malignant tumors, serum IGFBP-2 and IGF-II levels correlate positively with tumor markers and tumor stage and are inversely correlated with survival. Additionally, they are highly prognostic for metastasis and recurrent disease and are generally thought to reflect overall tumor burden. The mechanism for the IGF-II overexpression
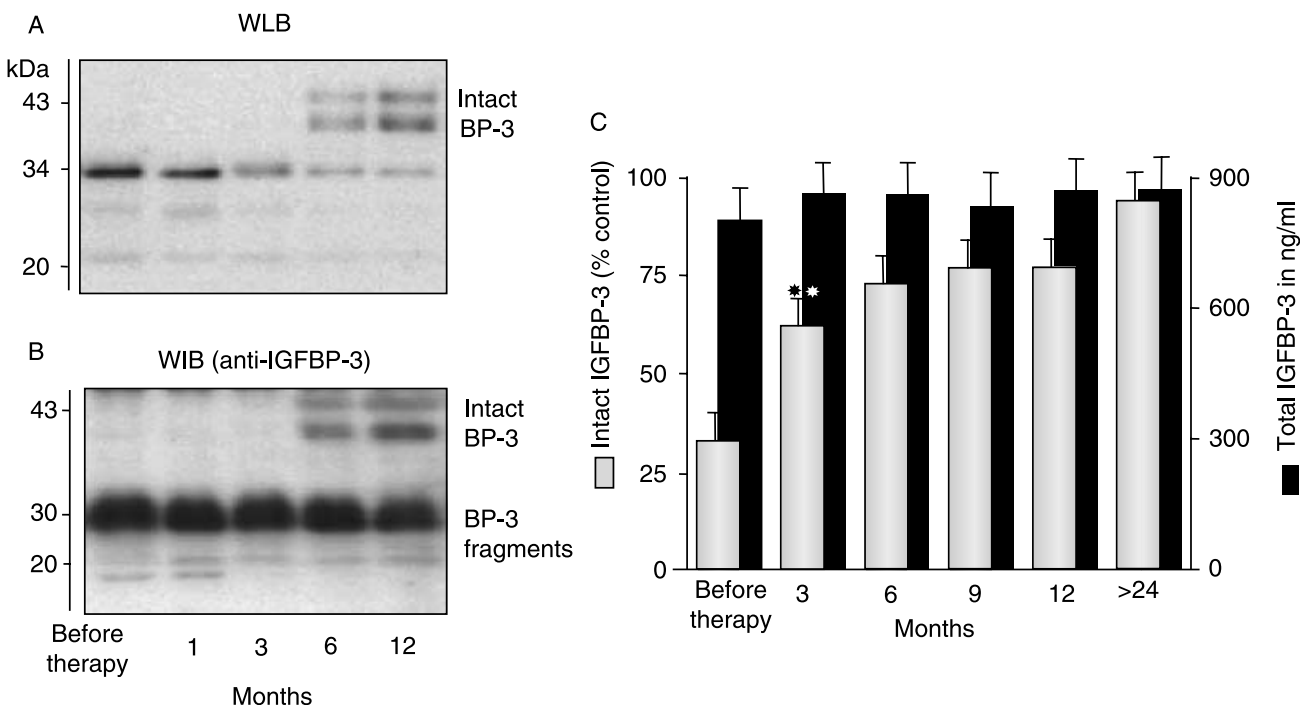

Figure 6 (A) Western ligand blot analysis (WLB) of serum samples of a single representative patient with testicular cancer showing markedly decreased IGFBP-3 bands (39-44 kDa) in untreated patients with testicular cancer with a significant increase after successful therapy. (B) Western immunoblots (WIB) using a specific anti-IGFBP-3 antibody show large amounts of the major $30 \mathrm{kDa}$ fragment of IGFBP-3 in untreated patients with testicular cancer and smaller amounts of IGFBP-3 fragments with 16 and $22 \mathrm{kDa}$ in addition to intact IGFBP-3. (C) Quantitative determination of IGFBP-3 serum levels in all 16 patients with testicular cancer using a specific RIA, detecting both total IGFBP-3, and its fragments shows no significant changes in IGFBP-3 serum levels before and after therapy (black bars), whereas densitometric quantification of intact IGFBP-3 bands of all western ligand blot analyses performed before and after therapy (gray bars) shows markedly decreased IGFBP-3 bands in untreated cancer patients, with a significant increase in intact IGFBP-3 after successful therapy, giving indirect evidence for an enhanced proteolytic activity for IGFBP-3 in untreated testicular cancer patients $\left({ }^{* \star} P<0.01\right)$. 
found in these tumors is thought to be related, in part, to pathological genomic imprinting. The IGF-II gene maps to the $11 \mathrm{p} 15$ chromosomal region and is maternally imprinted, thus that in the adult, IGF-II is exclusively expressed from the paternal allele. Abnormalities in the imprinted $11 \mathrm{p} 15$ region, involving the maternally imprinted IGF-II gene, are highly specific for these malignant tumors. These alterations include loss of heterozygosity with paternal duplication of the allele and, less frequently, loss of imprinting, excessive transcriptional activation, or loss of transcriptional suppression. Usually, these genetic alterations result in a strong IGF-II overexpression. Since malignant testicular tumors also show a consistent loss of genomic imprinting (29), it is tempting to speculate that the dysregulation of genetic imprinting in testicular cancer could be one reason for the observed increase in IGF-II serum levels in patients with testicular tumors.

Overexpression of IGFBP-2 is another common finding in malignant tumors. However, serum IGFBP-2 levels are not indicative of an increased cancer risk because in these tumors, serum IGFBP-2 levels are generally normal before the diagnosis of cancer $(12,30)$. Clinical data are paralleled by many in vitro studies, also showing IGFBP2 overexpression in various different cancer cell lines (31). In these tumor models, IGFBP-2 has been found to act in several different ways like a modulator of IGF action, but has also IGF-independent effects, both inducing gene expression important for proliferation, cell adhesion, cell migration, and apoptosis (31). However, the exact causes of the observed overexpression of IGFBP-2 are still unknown. The regulation of IGFBP-2 expression is highly complex and influenced by multiple hormones and growth factors (18). Known hormonal regulators of IGFBP-2 expression include growth hormone, IGF-I, transforming growth factor- $\beta$, interleukin- 1 , estradiol, glucocorticoids, insulin, and, of particular interest with regard to the data presented here, IGF-II and HCG. Published data of our own group show that postnatal overexpression of IGF-II in transgenic mice results in elevated circulating IGFBP-2 serum levels. In normal testicular cells, HCG stimulates IGFBP-2 expression and administration of HCG to rats increases IGFBP-2 gene expression even in extra-gonadal tissues like the mammary gland $(31,32)$. Since testicular non-seminomatous germ cell tumors can secrete large amounts of HCG as demonstrated in this study and show a direct correlation with the increase in IGFBP-2 serum levels, activation of the IGFBP-2 promoter by HCG, together with IGF-II, could be one explanation for the observed increase in IGFBP-2 serum levels in patients with testicular cancer, and therefore IGFBP-2, as demonstrated in our study, could serve as an additional biological marker in patients with testicular cancer. Our data show that IGFBP-2 was very sensitive in detecting disease activity, similar to the widely used standard tumor markers AFP and HCG, detecting active and recurrent disease in all investigated patients. Even though IGFBP-2 served as a very sensitive parameter for disease activity in our patients, due to its low specificity it was not superior to the tumor markers AFP and HCG and therefore will probably not be of additional value for routine clinical use in patients with non-seminomatous germ cell cancer showing strong tumor marker expression. However, it could be a valuable marker for disease activity in tumor marker negative testicular cancer patients like the most with seminomas. Since we did not investigate these tumor types due to a different study design, additional experiments are necessary to define the potential clinical role of IGFBP-2 as parameter of disease activity in tumor marker negative testicular cancer patients.

However, IGFBP-2 overexpression is not a phenomenon confined to testicular cancer and increased IGFBP-2 levels are not specific for indicating tumor disease, since an elevation of IGFBP-2 can be found in various different other conditions, usually associated with oxidative stress (33-35), where increased IGFBP-2 expression was used to activate defense mechanisms. These observations led to the question of whether the frequently observed overexpression of IGFBP-2 in malignant tumors is the cause of tumor formation or rather the consequence. However, the most recent data provide evidence that IGFBP-2 plays a direct role in the development and progression of malignant tumors. In human breast cancer cells, Perks et al. (36) have shown that IGFBP-2 and IGF-II are able to regulate the phosphatase and tensin homolog deleted on chromosome 10 (PTEN), one of the most frequently mutated tumor suppressor genes that counters the survival and proliferative actions of many growth factors. One of the few external controls of PTEN that have been identified is IGF-II that activates the signaling pathways, which PTEN itself then deactivates. PTEN can also downregulate IGF-II expression suggesting a tightly controlled feedback loop in which IGF-II can enhance PTEN expression and PTEN can suppress IGF-II expression $(36,37)$. This has been demonstrated recently in breast cancer cells and similar data have recently been published for the brain and prostate cancer (38). PTEN has also been investigated in testicular germ cell cancer and here a specific loss of PTEN has been reported from the pre-invasive to the invasive state, underlining the pathophysiological relevance of this tumor suppressor gene in testicular cancer $(38,39)$.

In addition to the markedly elevated IGF-II and IGFBP-2 serum levels in patients with non-seminomatous germ cell cancer found in this study, indirect evidence points to an enhanced proteolysis of IGFBP-3 in untreated nonseminoma patients. Similar to the modifications of IGF-II and IGFBP-2, the observed increased proteolysis of IGFBP3 is not only found in patients with testicular cancer, but represents a frequently observed alteration in many other tumors $(23,41-43)$. Recent studies identified several proteases secreted by different cancer cell lines which specifically cleaved IGFBP-3 and resulted in an increased IGF bioavailability. In breast cancer cells, the protease a disintegrin and metalloprotease 28 (ADAM28) has been 
recently demonstrated to be overexpressed, resulting in increased IGF-dependent carcinoma cell proliferation through cleavage of IGFBP-3 (44). Comparable results were published for colon cancer cell lines, where matrix metalloproteinase-7-induced proteolysis of IGFBP-3 resulted in increased IGF bioavailability thereby promoting cell survival (45). Recently, it has been demonstrated that the IGFBP-3 fragments itself can exert mitogenic effects in prostate carcinoma (PC)-3 cells (46). The exact mechanisms responsible for an increased proteolysis of IGFBP-3 are still unclear. However, published data provide evidence for a direct role of IGFBP-2 in inducing IGFBP-3 proteolysis in cancer, since injection of IGFBP-2-overexpressing human epidermoid carcinoma cells into nude mice resulted in a faster tumor development and three to four times larger tumors than in controls (43). Concomitant with IGFBP-2 expression in these tumors, an increase in IGFBP-3 proteolysis and an increase in the bioavailability of the IGF-II produced by the cells could be observed, resulting from amplified expression of tissuetype plasminogen activator and depression of its inhibitor observed in IGFBP-2-expressing xenografts (28). That the concept of proteinase inhibitor modulation might have an impact on IGF-induced tumorigenesis has recently been demonstrated in a murine hepatic tumor model, where IGF-II signaling in neoplastic proliferation was blocked by transgenic expression of the metalloproteinase inhibitor, resulting in a modulation of tumorigenesis by a proteinase-dependent reduction of the activity of the tumor-inducing mitogen IGF-II (47).

In summary, the presented data for the first time show significant alterations of the IGF system in patients with testicular cancer, similar to those observed previously in other common malignant tumors. The increasing knowledge about the molecular mechanisms of the complex regulation of IGF-II, the IGF-I receptor, and IGFBP 2 in growth control and tumorigenesis adds further support to the hypothesis that the IGF system is directly involved in the development and progression of malignant tumors. Because IGF targeting for anticancer therapy is rapidly becoming a clinical reality, a better understanding of these complex growth factor pathways is likely to have an impact on the design, mode of action, and clinical outcomes of newly developed drugs.

\section{Acknowledgements}

This study was supported by DFG grant WE 1356/4-2.

\section{References}

1 Bergstrom R, Adami HO, Mohner M, Zatonski W, Storm H, Ekbom A, Tretli S, Teppo L, Akre O \& Hakulinen T. Increase in testicular cancer incidence in six European countries: a birthcohort phenomenon. Journal of the National Cancer Institute 1996 $88727-733$.
2 Horwich A, Shipley J \& Huddart R. Testicular germ-cell cancer. Lancet 2006367 754-765.

3 American Joint Committee on Cancer: Manual for Staging Cancer. 5th ed. Chicago, III: American Joint Committee on Cancer; 1997

4 Schmoll HJ, Souchon R, Krege S, Albers P, Beyer J, Kollmannsberger C, Fossa SD, Skakkebaek NE, de Wit R, Fizazi K, Droz JP, Pizzocaro G, Daugaard G, de Mulder PH, Horwich A, Oliver T, Huddart R, Rosti G, Paz Ares L, Pont O, Hartmann JT, Aass N, Algaba F, Bamberg M, Bodrogi I, Bokemeyer C, Classen J, Clemm S, Culine S, de Wit M, Derigs HG, Dieckmann KP, Flasshove M, Garcia del Muro X, Gerl A, Germa-Lluch JR, Hartmann M, Heidenreich A, Hoeltl W, Joffe J, Jones W, Kaiser G, Klepp O, Kliesch S, Kisbenedek L, Koehrmann KU, Kuczyk M, Laguna MP, Leiva O, Loy V, Mason MD, Mead GM, Mueller RP, Nicolai N, Oosterhof GO, Pottek T, Rick O, Schmidberger H, Sedlmayer F, Siegert W, Studer U, Tjulandin S, von der Maase $\mathrm{H}$, Walz P, Weinknecht S, Weissbach L, Winter E, Wittekind C \& European Germ Cell Cancer Consensus Group. European consensus on diagnosis and treatment of germ cell cancer: a report of the European Germ Cell Cancer Consensus Group (EGCCCG). Annals of Oncology 200415 1377-1399.

5 Carver BS \& Sheinfeld J. Germ cell tumors of the testis. Annals of Surgical Oncology 200512 871-880.

6 Bridges B \& Hussain A. Testicular germ cell tumors. Current Opinion in Oncology $200719222-228$.

7 Reuter VE. Origins and molecular biology of testicular germ cell tumors. Modern Pathology 200518 S51-S60.

8 Christoph F, Kempkensteffen C, Weikert S, Krause H, Schostak M, Miller K \& Schrader M. Frequent epigenetic inactivation of p53 target genes in seminomatous and nonseminomatous germ cell tumors. Cancer Letters 2007247 137-142.

9 Renehan AG, Zwahlen M, Minder C, O'Dwyer ST, Shalet SM \& Egger M. Insulin-like growth factor (IGF)-I, IGF binding protein-3, and cancer risk: systematic review and meta-regression analysis. Lancet 20043631346.

10 Czech MP. Signal transmission by the insulin-like growth factors. Cell $198959235-238$.

11 Jones JI \& Clemmons DR. Insulin-like growth factors and their binding proteins: biological actions. Endocrine Reviews 199516 3-34.

12 Baxter RC \& Martin JL. Binding proteins for the insulin-like growth factors: structure, regulation and function. Progress in Growth Factor Research 19891 49-68.

13 Samani AA, Yakar S, LeRoith D \& Brodt P. The role of the IGF system in cancer growth and metastasis: overview and recent insights. Endocrine Reviews 200728 20-47.

14 Neuvians TP, Gashaw I, Hasenfus A, Häcker A, Winterhager E \& Grobholz R. Differential expression of IGF components and insulin receptor isoforms in human seminoma versus normal testicular tissue. Neoplasia $20057446-456$.

15 Zhou J \& Bondy C. Anatomy of the insulin-like growth factor system in the human testis. Fertility and Sterility $199360897-904$.

16 Vannelli BG, Barni T, Orplando C, Natali A, Serio M \& Balboni GC. Insulin-like growth factor-I (IGF-I) and IGF-I receptor in human testis: an immunohistochemical study. International Journal of Andrology $19871079-84$.

17 Drescher B, Lauke H, Hartmann M, Davidoff MS \& Zumkeller W. Immunohistochemical pattern of insulin-like growth factor (IGF) I, IGF II and IGF binding proteins 1 to 6 in carcinoma in situ of the testis. Molecular Pathology 199750 298-303.

18 Engstrom W, Hopkins B \& Schofield P. Expression of growth regulatory genes in primary human testicular neoplasms. International Journal of Andrology 198710 79-84.

19 Rajaram S, Baylink DJ \& Mohan S. Insulin-like growth factorbinding proteins in serum and other biological fluids: regulation and functions. Endocrine Reviews 199718 801-831.

20 Weber MM, Auernhammer CJ, Lee PD, Engelhardt D \& Zachoval R. Insulin-like growth factors and insulin-like growth factor binding proteins in adult patients with severe liver disease before and after orthotopic liver transplantation. Hormone Research 200257 105-112. 
21 Gerl A, Lamerz R, Mann K, Clemm C \& Wilmanns W. Is serum tumor marker half-life a guide to prognosis in metastatic nonseminomatous germ cell tumors? Anticancer Research 1997 17 3047-3049.

22 Weber MM, Simmler P, Fottner C \& Engelhardt D. Insulin-like growth factor II (IGF-II) is more potent than IGF-I in stimulating cortisol secretion from cultured bovine adrenocortical cells: interaction with the IGF-I receptor and IGF-binding proteins. Endocrinology $19951363714-3720$.

23 Weber MM, Kiess W, Beikler T, Simmler P, Reichel M, Adelmann B, Kessler U \& Engelhardt D. Identification and characterization of insulin-like growth factor I (IGF-I) and IGF-II/mannose-6phosphate (IGF-II/M6P) receptors in bovine adrenal cells. European Journal of Endocrinology 1994130 265-270.

24 Mehrian-Shai R, Chen CD, Shi T, Horvath S, Nelson SF, Reichardt JKV \& Sawyers CL. Insulin growth factor-binding protein 2 is a candidate biomarker for PTEN status and PI3K/Akt pathway activation in glioblastoma and prostate cancer. PNAS $2007 \mathbf{1 0 4} 5563-5568$.

25 Khandwala HM, McCutcheon IE, Flyvbjerg A \& Friend KE. The effects of insulin-like growth factors on tumorigenesis and neoplastic growth. Endocrine Reviews 200021 215-244.

26 Boulle N, Logie A, Gicquel C, Perin L \& Le Bouc Y. Increased levels of insulin-like growth factor II (IGF-II) and IGF-binding protein-2 are associated with malignancy in sporadic adrenocortical tumors. Journal of Clinical Endocrinology and Metabolism $1998 \mathbf{8 3}$ 1713-1720.

27 Zavos C, Andreadis C, Diamantopoulos N \& Mouratidou D. A hypothesis on the role of insulin-like growth factor I in testicular germ cell tumours. Medical Hypotheses 200463 511-514.

28 Frommer KW, Reichenmiller K, Schutt BS, Hoeflich A, Ranke MB, Dodt G \& Elmlinger MW. IGF-independent effects of IGFBP-2 on the human breast cancer cell line Hs578T. Journal of Molecular Endocrinology 200637 13-23.

29 Van Gurp RJ, Oosterhuis JW, Kalscheuer V, Mariman EC \& Looijenga LH. Biallelic expression of the H19 and IGF2 genes in human testicular germ cell tumors. Journal of the National Cancer Institute 199486 1070-1075.

30 Holly J \& Perks C. The role of Insulin-like growth factor binding proteins. Neuroendocrinology 200683 154-160.

31 Pollak NM, Schernhammer ES \& Hankinson SE. Insulin-like growth factors and cancer. Nature Reviews. Cancer 200414 277-286.

32 Hoeflich A, Reisinger R, Lahm H, Kiess W, Blum WF, Kolb HJ, Weber MM \& Wolf E. Insulin-like growth factor-binding protein 2 in tumorigenesis - protector or promoter? Cancer Research 2001 $618601-8610$.

33 Wang D, Nagpal ML, Lin T, Shimasaki S \& Ling N. Insulin-like growth factor-binding protein-2: the effect of human chorionic gonadotropin on its gene regulation and protein secretion and its biological effects in rat Leydig cells. Molecular Endocrinology 1994 8 69-76.

34 Besnard V, Corroyer S, Trugnan G, Chadelat K, Nabeyrat E, Cazals V \& Clement A. Distinct patterns of insulin-like growth factor binding protein (IGFBP)-2 and IGFBP-3 expression in oxidant exposed lung epithelial cells. Biochimica et Biophysica Acta $2001 \mathbf{1 5 3 8} 47-58$.

35 Cazals V, Nabeyrat E, Corroyer S, de Keyzer Y \& Clement A. Role for NF-KB in mediating the effects of hyperoxia on IGF-binding protein 2 promoter activity in lung alveolar epithelial cells. Biochimica et Biophysica Acta 19991448 349-362.
36 Perks CM, Vernon EG, Rosendahl AH, Tonge D \& Holly JM. IGF-II and IGFBP-2 differentially regulate PTEN in human breast cancer cells. Oncogene $2007265966-5972$.

37 Moorehead RA, Hojilla CV, De Belle I, Wood GA, Fata JE, Adamson ED, Watson KL, Edwards DR \& Khokha R. Insulin-like growth factor-II regulates PTEN expression in the mammary gland. Journal of Biological Chemistry $2003 \mathbf{2 7 8} 50422-50427$.

38 Kang-Park S \& Lee YI. PTEN modulates insulin-like growth factor II (IGF-II)-mediated signaling; the protein phosphatase activity of PTEN downregulates IGF-II expression in hepatoma cells. FEBS Letters $2003 \mathbf{5 4 5} 203-208$.

39 Dunlap SM, Celestino J, Wang H, Jiang R, Holland EC, Fuller GN \& Zhang W. Insulin-like growth factor binding protein 2 promotes glioma development and progression. PNAS $2007 \mathbf{1 0 4}$ 11736-11741.

40 Di Vizio D, Cito L, Boccia A, Chieffi P, Insabato L, Pettinato G, Motti ML, Schepis F, D’Amico W, Fabiani F, Tavernise B, Venuta S, Fusco A \& Viglietto G. Loss of the tumor suppressor gene PTEN marks the transition from intratubular germ cell neoplasias (ITGCN) to invasive germ cell tumors. Oncogene $2005 \mathbf{2 4}$ 1882-1894.

41 Helle SI, Geisler S, Aas T, Paulsen T, Holly JM \& Lønning PE. Plasma insulin-like growth factor binding protein-3 proteolysis is increased in primary breast cancer. British Journal of Cancer 2001 $8574-77$.

42 Grønbaek H, Tanos V, Meirow D, Peretz T, Raz I \& Flyvbjerg A. Effects of tamoxifen on insulin-like growth factors, IGF binding proteins and IGFBP-3 proteolysis in breast cancer patients. Anticancer Research $2003232815-2820$.

43 Baciuchka M, Remacle-Bonnet M, Garrouste F, Favre R, Sastre B \& Pommier G. Insulin-like growth factor (IGF)-binding protein-3 (IGFBP-3) proteolysis in patients with colorectal cancer: possible association with the metastatic potential of the tumor. International Journal of Cancer 1998 79 460-467.

44 Crown AL, Cottle K, Lightman SL, Falk S, Mohamed-Ali V, Armstrong L, Millar AB \& Holly JM. What is the role of the insulinlike growth factor system in the pathophysiology of cancer cachexia, and how is it regulated? Clinical Endocrinology 2002 56 723-733.

45 Mitsui Y, Mochizuki S, Kodama T, Shimoda M, Ohtsuka T, Shiomi T, Chijiiwa M, Ikeda T, Kitajima M \& Ohtsuka Y. ADAM28 is overexpressed in human breast carcinomas: implications for carcinoma cell proliferation through cleavage of insulin-like growth factor binding protein-3. Cancer Research $2006669913-9920$.

46 Angelloz-Nicoud P, Lalou C \& Binoux M. Prostate carcinoma (PC-3) cell proliferation is stimulated by the $22-25-\mathrm{kDa}$ proteolytic fragment (1-160) and inhibited by the 16-kDa fragment (1-95) of recombinant human insulin-like growth factor binding protein-3. Growth Hormone and IGF Research 1998 8 71-75.

47 Martin DC, Fowlkes JL, Babic B \& Khokha R. Insulin-like growth factor II signaling in neoplastic proliferation is blocked by transgenic expression of the metalloproteinase inhibitor TIMP-1. Journal of Cell Biology 1999146 881-892.

Received 23 April 2008

Accepted 16 May 2008 